\title{
Pemanfaatan video pembelajaran berbasis Geogebra untuk meningkatkan kemampuan pemahaman konsep matematis siswa SMK
}

\author{
Erdawati Nurdin *, Aulia Ma'aruf, Zubaidah Amir, Risnawati, Noviarni, Memen Permata Azmi \\ Pendidikan Matematika, Universitas Islam Negeri Sultan Syarif Kasim Riau \\ Jalan HR. Soebrantas No. 155 Panam, Pekanbaru 28293, Indonesia \\ E-mail: erdawati.nurdin@uin-suska.ac.id \\ * Corresponding Author
}

\section{ARTICLE INFO}

\section{Article history}

Received: 6 February 2018;

Revised: 16 August 2018;

Accepted: 30 August 2019

\section{Keywords}

pemahaman konsep

matematis; software

Geogebra; video

pembelajaran;

understanding mathematical

concepts; Geogebra

software; learning video

\begin{abstract}
Penelitian ini bertujuan untuk mendeskripsikan efektivitas pemanfaatan video pembelajaran berbasis Geogebra dalam meningkatkan kemampuan pemahaman konsep matematis siswa Sekolah Menengah Kejuruan. Desain penelitian kuasi eksperimen ini adalah nonequivalent control group design. Teknik pengumpulan data yang digunakan adalah wawancara dan tes kemampuan pemahaman konsep matematis. Analisis data dalam penelitian ini menggunakan uji U Mann-Whitney. Hasil analisis data menunjukkan bahwa peningkatan kemampuan pemahaman konsep matematis siswa yang menggunakan video pembelajaran berbasis Geogebra lebih baik dibandingkan siswa yang belajar dengan pembelajaran konvensional. Video pembelajaran berbasis Geogebra efektif dan berpengaruh positif terhadap peningkatan kemampuan pemahaman konsep matematis siswa. Video pembelajaran berbasis Geogebra ini dapat dijadikan sebagai salah satu media pembelajaran untuk meningkatkan kemampuan pemahaman konsep matematis siswa.
\end{abstract}

This study aimed to describe the effectiveness of the use of learning video-based Geogebra to improve Vocational High School students' ability in understanding mathematical concepts. This quasi-experimental research was a non-equivalent control group design. Data collection was done through interviews and tests of students' ability in understanding mathematical concepts. The data analysis uses the U Mann-Whitney test. The results of this research show that the improvement of students' ability to understanding a mathematical concept by using learning video-based Geogebra was better than students who learn by using conventional learning. Learning video-based Geogebra was effective and have a positive effect on improving students' mathematical concepts. Learning video-based Geogebra could be used as one of the learning media to improve students' mathematical concepts.

This is an open access article under the CC-BY-SA license.

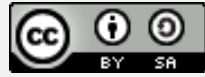

How to Cite: Nurdin, E., Ma'aruf, A., Amir, Z., Risnawati, R., Noviarni, N., \& Azmi, M. (2019). Pemanfaatan video pembelajaran berbasis Geogebra untuk meningkatkan kemampuan pemahaman konsep matematis siswa SMK. Jurnal Riset Pendidikan Matematika, 6(1), 87-98. doi:https://doi.org/10.21831/jrpm.v6i1.18421

\section{PENDAHULUAN}

Salah satu tujuan utama dalam pembelajaran matematika adalah siswa harus memahami konsep (Kesumawati, 2008, p.233; Murizal, Yarman, \& Yerizon, 2012, p.19). Peraturan Menteri Pendidikan dan Kebudayaan Republik Indonesia Nomor 21 Tahun 2016 tentang standar isi pendidikan dasar dan menengah menyebutkan bahwa salah satu kompetensi inti bidang pengetahuan yang harus dimiliki oleh siswa sekolah menengah adalah kemampuan memahami konsep (Kementerian Pendidikan dan 
Kebudayaan Republik Indonesia, 2016, p.11). Annajmi (2016, p.2) menyatakan bahwa pemahaman konsep menjadi dasar dalam mengerjakan matematika. Artinya, setiap siswa wajib memiliki kemampuan pemahaman konsep yang baik agar dapat menyelesaikan persoalan matematika.

Pada kenyataannya, masih banyak siswa di Indonesia yang masih lemah dalam memahami konsep matematika. Rendahnya pemahaman konsep matematika siswa Indonesia salah satunya tampak pada hasil survei yang dilakukan oleh Programme for International Student Assessment (PISA) terhadap pelajar berusia 15 tahun. Pada tahun 2015 (OECD, 2016), skor prestasi belajar matematika siswa Indonesia hanya 403 poin, nilai ini masih jauh di bawah skor rata-rata internasional yaitu 493 dan jauh lebih rendah dibanding nilai yang diperoleh negara ASEAN lainnya, seperti Thailand (421), Vietnam (525) dan Singapura (556). Pada tahun tersebut Indonesia hanya menempati peringkat 64 dari 72 negara peserta (OECD, 2016, p.5). Hasil survei Trends International Mathematics and Science Study (TIMSS) tahun 2015 juga menunjukkan hal yang sama, rata-rata skor prestasi matematika siswa Indonesia hanya berada pada peringkat 44 dari 49 negara yang berpartisipasi dan skor rata-rata yang diperoleh adalah 397, jauh di bawah rata-rata internasional yaitu 550 (Mullis, Martin, Foy, \& Hooper, 2016, p.15). Berkaca pada hasil kedua survei internasional tersebut, dapat dipahami bahwa masih lemahnya pemahaman matematis siswa di Indonesia. Hal ini didukung pula oleh penelitian yang dilakukan oleh Azis dan Sugiman (2015, p.172) yang mengungkapkan bahwa siswa mengalami kesulitan konseptual dalam belajar matematika karena tidak dapat mengingat dan memahami konsep yang diperlukan untuk menyelesaikan permasalahan.

Faktor lain yang juga memberikan pengaruh terhadap rendahnya penguasaan siswa Indonesia di bidang matematika ialah matematika yang bersifat abstrak, sehingga banyak siswa yang menganggap matematika sulit, membingungkan, bahkan menakutkan. Amir (2015, p.61) menyatakan bahwa pembelajaran matematika yang biasa disajikan kepada siswa hanya berupa kumpulan rumus, abstrak, teoritis dan tanpa makna. Hal ini diperparah oleh teknik pembelajaran dua langkah yang selama ini dilakukan dari generasi ke generasi, yaitu: (1) guru menunjukkan bagaimana cara menyelesaikan contoh atau persoalan tertentu, kemudian (2) siswa meniru prosedur yang diberikan secara mekanis untuk menjawab contoh soal yang serupa (Wahyudin, 2008, p.76). Hal ini menyebabkan siswa belajar tanpa pemahaman mengenai arti fakta-fakta dasar dan bagaimana algoritma bekerja. Oleh sebab itu, guru dituntut untuk dapat memanipulasi pembelajaran sedemikian rupa, sehingga dapat membantu siswa baik memahami konsep, maupun mengembangkan kecakapan daya matematisnya (Ambussaidi \& Yang, 2019).

Geometri transformasi merupakan salah satu materi pokok yang wajib dipelajari oleh siswa sekolah menengah atas dan kejuruan. Geometri transformasi merupakan bagian dari geometri yang membahas perubahan (letak, bentuk, penyajian) yang didasarkan dengan gambar dan matriks (Marzuqo, 2014, p.1). Dalam pengajaran materi geometri transformasi, guru perlu menggunakan suatu media pembelajaran yang memudahkan dan mempersingkat waktu untuk menggambar, serta membantu menjadikan perubahan yang terjadi pada objek geometri terlihat jelas dan nyata. Hal tersebut bertujuan agar pembelajaran lebih efektif dan efesien, serta lebih banyak waktu untuk mengeksplorasi objek geometri, dan akhirnya dapat membantu siswa memahami konsep geometri transformasi dengan baik dan mengembangkan kecakapan matematisnya.

Penggunaan media pembelajaran yang tepat dapat menjadi perantara bagi siswa untuk memahami materi dan meningkatkan kualitas pembelajaran (Baharuddin, 2014, p.248). Beberapa manfaat penggunaan media pembelajaran adalah memperjelas makna dari suatu materi, tidak hanya bersifat verbalisitik, pembelajaran menjadi lebih bervariasi, aktif, menarik dan mengatasi keterbatasan ruang (Trianto, 2011, p.234). Media pembelajaran merupakan perantara yang bersifat menimbulkan daya tarik/perhatian siswa (student interest) dalam kegiatan belajar serta tujuan yang ingin dicapai (Hosnan, 2014, p.111). Dalam proses pembelajaran guru perlu merencanakan media pembelajaran dengan baik karena media dapat menjadikan hal yang abstrak menjadi konkret, meningkatkan daya serap serta membantu menerangkan hal-hal yang sulit dipahami secara verbal (Hamzah \& Muhlisrarini, 2014, p.96). Dengan demikian media pembelajaran memiliki peran penting dalam pembelajaran matematika.

Seiring dengan perkembangan ilmu pengetahuan dan teknologi, penerapan teknologi dalam pembelajaran dapat mempermudah siswa mempelajari konsep matematika (Khuzaini \& Santosa, 2016, p.89). Penggunaan teknologi dalam pembelajaran memunculkan berbagai media pembelajaran yang semakin canggih dan diintegrasikan dengan komputer, seperti film, video, electronic distribution system, buku dan media cetak, media audio, multimedia, dan video interaktif (Hosnan, 2014, p.116- 
117). Penggunaan dan pemanfaatan alat dan media pembelajaran penerapan hasil teknologi ini ditujukan untuk meningkatkan efektivitas dan efisiensi pembelajaran (Nurdin \& Nufus, 2017, p.49).

Salah satu media yang paling dinamik dan efektif dalam menyampaikan suatu informasi adalah video (Munir, 2013, p.289). Istilah video berasal dari bahasa Latin, yaitu dari kata vidi atau visum, artinya melihat atau mempunyai daya penglihatan (Munir, 2013, p.289). Dalam kamus Bahasa Indonesia video diartikan sebagai teknologi pengirim sinyal elektronik dari suatu gambar bergerak. Agnew dan Kellerman (Munir, 2013, p.18) mendefinisikan video sebagai media digital yang menunjukkan susunan gambar bergerak dan dapat memberikan ilusi/fantasi. Prastowo (2015, p.300) mendefinisikan video sebagai tayangan gambar bergerak yang disertai dengan suara. Video merupakan suatu media pembelajaran audio visual yang memadukan materi visual dan materi auditif. Materi visual menjadikan siswa mampu menangkap pesan belajar melaui visualisasi (pengamatan) dan materi auditif menjadikan siswa mampu menerima pesan melalui pendengaran (Busyaeri, Udin, \& Zaenudin, 2016, p.122). Kombinasi dua materi tersebut ditujukan untuk menciptakan pembelajaran yang berkualitas (Prastowo, 2011, p.301). Media audio visual dapat menjadi alternatif sarana optimalisasi proses pembelajaran dan menjadikan pembelajaran lebih efektif, baik dari segi waktu maupun materi yang disampaikan (Haryoko, 2009, p.2).

Video memiliki beberapa keunggulan, yaitu menciptakan kemandirian belajar, komunikatif dan dapat diulang, menampilkan sesuatu dengan detail dan kompleks, dapat diulang, diperlambat, bahkan diperbesar dan membandingkan antara dua atau lebih adegan secara bersamaan (Majid, 2012, p.180). Keunggulan inilah yang menjadi daya tarik yang diminati oleh siswa, pembelajaran menjadi lebih konkret, tidak monoton, tidak membosankan dan akhirnya mampu meningkatkan pemahaman siswa terhadap suatu konsep. Daya tarik penggunaan video menimbulkan persepsi positif yang akhirnya memotivasi siswa untuk belajar matematika (Purwanti, 2015, p.47). Hasil penelitian Baharuddin (2014, p.255) menunjukkan bahwa penggunaan media video tutorial efektif dalam meningkatkan minat dan hasil belajar matematika siswa.

Terdapat beberapa jenis video pembelajaran yang dapat digunakan, diantaranya lecture capture, taking head video, voice over presentation dan interactive video lecture. Lecture capture merupakan video pembelajaran yang direkam secara langsung. Taking head video adalah perekaman video penyampaian materi oleh instruktur menggunakan webcam. Komponen utama voice over presentation adalah presentasi menggunakan power point, dilengkapi dengan suara selama penayangan slide. Terakhir, interactive video lecture, meliputi video, audio, power point dan fitur lainnya yang diperlukan dalam penayangan video interaktif (Vieira, Lopes, \& Soares, 2014, p.751).

Selain kelebihan, video juga memiliki beberapa kekurangan. Menurut Johari, Hasan, dan Rakhman (2014, p.10), kekurangan video diantaranya adalah video memerlukan bantuan media lain, seperti komputer, sound system/speaker, proyektor dan layar infokus, proses pembuatan video memakan biaya yang cukup mahal, diperlukan waktu yang panjang untuk menyelesaikan sebuah video. Kelemahan lain video terdapat dalam proses pembuatannya. Video tidak dapat berdiri sendiri, diperlukan suatu program yang menjadi bagian rangkaian kegiatan produksi video (Hamzah \& Muhlisrarini, 2014, p.104).

Software Geogebra dapat menjadi alternatif program yang dapat membantu memudahkan dalam pembuatan video pembelajaran matematika. Geogebra dapat digunakan untuk mendukung pembelajaran yang melibatkan berbagai ide matematis dan dapat menyajikan berbagai representasi dinamis dalam desain pembelajaran (Bu \& Haciomeroglu, 2010, p.8). Geogebra merupakan kepanjangan dari Geometri dan Algebra/aljabar dan pertama kali dirancang oleh Markus Hohenwarter pada tahun 2001 (Mahmudi, 2010, p.470). Sesuai dengan namanya, software Geogebra diciptakan sebagai alat bantu pembelajaran geometri sekaligus aljabar. Geogebra dapat dimanfaatkan sebagai alat bantu visualisasi yang efektif dan efisien (Nur, 2016, p.18). Alviah dan Rudhito (2012, p.280) menyebutkan bahwa Geogebra merupakan suatu software yang memiliki fasilitas animasi dan gerak yang dapat memberikan visualisasi yang lebih jelas bagi siswa. Hohenwarter dan Funchs (Mahmudi, 2010, p.471) mengungkapkan berbagai pemanfaatan Geogebra dalam pembelajaran matematika seperti sebagai media visualisasi, demonstrasi, alat bantu konstruksi dan proses penemuan konsep-konsep geometri.

Pembelajaran matematika menggunakan software Geogebra memberikan banyak kemudahan dan keuntungan (Mahmudi, 2010, p. 471), diantaranya video dapat menjadikan pembelajaran matematika lebih efektif dan efesien karena mempersingkat waktu yang diperlukan untuk menggambar dan lukisan yang diperoleh lebih tepat dan detail, didukung dengan fasilitas animasi dan gerakan sehingga dapat 
meningkatkan pemahaman konsep geometri melalui visualisai yang lebih dinamis, dapat digunakan sebagai umpan balik untuk mengecek kebenaran gambar yang dilukis, dan memberikan kemudahan dalam proses penyelidikan sifat-sifat objek geometri.

Pada penelitian ini, jenis video yang digunakan adalah video over presentation yang menampilkan berbagai tayangan mengenai materi geometri transformasi yang disertai suara yang mendeskripsikan setiap tampilan materi. Materi yang disajikan dalam video dirancang sedemikian rupa agar memiliki struktur yang koheren dan mampu menyampaikan pesan yang dapat membimbing siswa memahami materi. Sebagaimana yang diungkapkan oleh Mayer (2009, p.77) bahwa terdapat beberapa persyaratan agar multimedia, salah satunya video pembelajaran memberikan manfaat bagi siswa. Syarat pertama yaitu materi yang disajikan harus punya struktur yang koheren dan syarat kedua yaitu pesannya harus memberi bimbingan untuk membangun suatu model. Mengacu pada pendapat tersebut, produksi video pembelajaran dibuat dengan bantuan software Geogebra. Video pembelajaran yang ditampilkan memuat gambar (visual) sekaligus penjelasan (audio) yang dipadukan dengan animasi (gerak). Video pembelajaran menayangkan perubahan posisi, bentuk dan ukuran objek-objek geometri. Video pembelajaran diberikan secara klasikal di depan kelas, selama 20-30 menit setiap pertemuannya. Penayangan video selama pembelajaran dikontrol oleh guru. Guru dapat melakukan pause (tunda) untuk memberikan penjelasan yang lebih detail mengenai gambar yang sedang ditampilkan, kemudian melanjutkannya kembali.

Berdasarkan latar belakang masalah dan kajian literatur yang telah dikemukakan, dapat dipahami bahwa pemanfaatan video pembelajaran berbasis Geogebra dapat dijadikan alternatif untuk meningkatkan pemahaman konsep siswa, terutama pada materi geometri. Dengan demikian tujuan penelitian ini adalah untuk mendeskripsikan pengaruh pemanfaatan video pembelajaran berbasis Geogebra terhadap peningkatan kemampuan pemahaman konsep matematis siswa Sekolah Menengah Kejuruan (SMK).

\section{METODE}

Jenis penelitian yang dilakukan adalah penelitian kuasi eksperimen. Penelitian kuasi eksperimen merupakan penelitian yang dilakukan untuk melihat pengaruh suatu variabel tertentu terhadap variabel lain dalam kondisi tertentu, memiliki kelas kontrol tetapi tidak dapat berfungsi sepenuhnya untuk mengontrol, karena sampelnya tidak dipilih secara acak (Sugiyono, 2014, p.77). Karena populasi pada penelitian ini merupakan siswa sekolah, yaitu siswa Sekolah Menengah Kejuruan (SMK), maka sampel tidak dapat dipilih secara acak murni. Sampel pada penelitian ini dipilih menggunakan teknik purposive sampling, yaitu pemilihan sampel dengan pertimbangan tertentu (Riduwan, 2013, p.63). Sampel pada penelitian ini adalah siswa kelas XI SMK, yaitu 35 orang siswa kelas XI.1 Farmasi sebagai kelompok eksperimen dan 38 orang siswa kelas XI.2 Farmasi sebagai kelompok kontrol. Siswa kelas XI dianggap sebagai kelas yang ideal untuk dijadikan sampel penelitian, karena siswa kelas X masih dalam tahap adaptasi dari jenjang SMP, sedangkan siswa kelas XII memasuki tahap persiapan menghadapi ujian nasional. Penelitian dilakukan di SMK Farmasi Ikasari Pekanbaru, Indonesia, tahun pelajaran 20152016.

Untuk melihat pengaruh penggunaan video pembelajaran berbasis Geogebra terhadap pemahaman konsep siswa, maka diperlukan kelompok kontrol sebagai pembanding, sehingga desain penelitian yang sesuai adalah quasi eksperiment noneqivalent control group design (Sugiyono, 2014, p.79). Pada penelitian ini, kelompok eksperimen mendapatkan pembelajaran dengan memanfaatkan video berbasis Geogebra, sedangkan kelompok kontrol memperoleh pembelajaran konvensional. Kelompok kontrol dan kelompok eksperimen diberikan tes awal sebelum dilakukan pembelajaran dan tes akhir setelah pembelajaran selesai. Tes awal diberikan untuk melihat kemampuan awal pemahaman konsep matematis siswa, dan tes akhir menunjukkan kemampuan pemahaman konsep matematis siswa setelah pembelajaran. Untuk melihat peningkatan kemampuan pemahaman konsep matematis siswa digunakan gain ternormalisasi (n-gain). Adapun hipotesis yang diuji pada penelitian ini yaitu:

$\mathrm{H}_{0}$ : Tidak terdapat perbedaan peningkatan kemampuan pemahaman konsep matematis siswa yang belajar menggunakan video pembelajaran berbasis Geogebra dengan siswa yang memperoleh pembelajaran konvensional. 
$\mathrm{H}_{\mathrm{a}}$ : Terdapat perbedaan peningkatan kemampuan pemahaman konsep matematis siswa yang belajar menggunakan video pembelajaran berbasis Geogebra dengan siswa yang memperoleh pembelajaran konvensional.

\section{Teknik Pengumpulan Data}

Teknik pengumpulan data yang digunakan pada penelitian ini adalah teknik wawancara dan teknik tes. Teknik wawancara dilakukan untuk mengetahui potensi yang dimiliki oleh siswa serta kecukupan sarana dan prasarana sekolah. Hal ini dilakukan untuk mengurangi pengaruh variabel lain terhadap proses pembelajaran, seperti penguasaan siswa terhadap materi prasyarat dan ketersedian alat pendukung pembelajaran menggunakan video berbasis Geogebra, yaitu komputer/laptop, infokus, layar infokus dan sound system. Wawancara dilakukan kepada guru matematika di kelas XI, karena guru tersebut dianggap paling mengerti kondisi siswa kelas XI yang menjadi sampel penelitian ini.

Data berupa kemampuan pemahaman konsep matematis siswa diperoleh melalui teknik tes. Tes merupakan teknik pengumpulan data penelitian yang bertujuan untuk mengukur kemampuan seseorang (Mulyatiningsih, 2013, p.25). Sebelum digunakan soal tes yang diberikan telah divalidasi oleh validator ahli dan dinyatakan valid untuk digunakan. Validator ahli terdiri dari dua orang dosen pendidikan matematika dan seorang guru matematika. Soal tes disajikan dalam bentuk tes awal dan tes akhir. Roestiyah (Ma'ruf, 2016, p. 56) menyatakan bahwa soal tes awal dan tes akhir dapat berupa soal yang identik. Soal tes awal diberikan sebelum pembelajaran dilakukan, sedangkan tes akhir diujikan setelah pembelajaran selesai. Tes disusun berdasarkan indikator kemampuan pemahaman konsep matematis. Indikator-indikator tersebut meliputi kemampuan menyatakan ulang konsep yang telah dipelajari, kemampuan mengklasifikasi objek-objek berdasarkan dipenuhi tidaknya persyaratan yang membentuk konsep tersebut, kemampuan menerapkan konsep secara algoritma, kemampuan memberikan contoh dan counter example dari konsep yang telah dipelajari, kemampuan menyajikan konsep dalam berbagai bentuk representasi matematika, kemampuan mengaitkan berbagai konsep dan kemampuan mengembangkan syarat perlu dan syarat cukup suatu konsep (Afgani, 2011, p.4.5-4.6).

\section{Teknik Analisis Data}

Teknik analisis data yang dilakukan pada penelitian ini adalah analisis data deskriptif dan analisis data inferensial. Analisis data deskriptif dilakukan untuk memberikan gambaran kemampuan pemahaman konsep matematis siswa sebelum dan sesudah pembelajaran. Analisis inferensial dilakukan untuk menarik kesimpulan mengenai pengaruh penggunaan video pembelajaran berbasis Geogebra terhadap peningkatan kemampuan pemahaman konsep matematis siswa.

Data berupa skor tes kemampuan pemahaman konsep matematis siswa dianalisis menggunakan bantuan software SPSS 17. Peningkatan kemampuan pemahaman konsep matematis siswa sebelum dan sesudah pembelajaran dengan video berbasis Geogebra dihitung menggunakan rumus gain ternormalisasi (n-gain) (Meltzer, 2002, p.1260), dengan Persamaan Rumus 1.

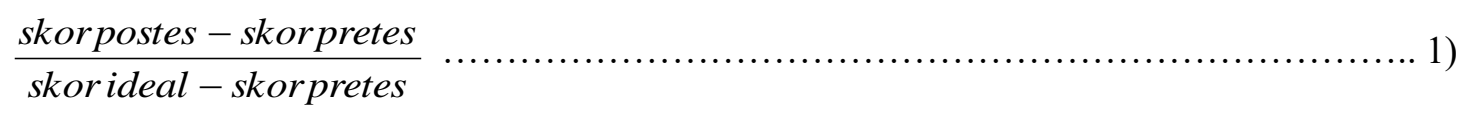

Hake (1998, p.63) mengklasifikasikan nilai gain ternormalisasi menjadi tiga kelompok. Kelompok high gain untuk nilai gain lebih dari 0,7. Kelompok medium gain untuk nilai gain diantara 0,3 dan 0,7. Kelompok low gain untuk nilai gain kurang dari 0,3.

Sebelum melakukan uji pengaruh penggunaan video pembelajaran berbasis Geogebra terhadap peningkatan rata-rata skor kemampuan pemahaman konsep matematis siswa, terlebih dahulu dilakukan uji asumsi. Uji asumsi yang dilakukan adalah uji normalitas dan uji homogenitas. Uji normalitas dan uji homogenitas terhadap rata-rata skor peningkatan (n-gain) kemampuan pemahaman konsep matematis siswa perlu dilakukan untuk menentukan uji inferensial yang akan digunakan. Karena data yang diperoleh lebih dari 30, maka untuk menguji kenormalan distribusi data digunakan uji Shapiro-Wilk dan untuk melihat kehomogenan varians data digunakan uji statistik Levene dengan taraf signifikansi 0,05. Jika sebaran data yang diperoleh normal dan homogen, maka dilanjutkan dengan melakukan uji perbedaan rata-rata dengan uji compare mean independent samples test (uji-t). Sedangkan, jika data tidak berdistribusi normal, maka uji yang dilakukan adalah uji statistik non-parametrik U MannWhitney. 


\section{HASIL DAN PEMBAHASAN}

\section{Hasil}

Sebelum melakukan proses pembelajaran menggunakan video berbasis Geogebra, terlebih dahulu peneliti melakukan wawancara terhadap guru matematika di kelas XI SMK Farmasi Ikasari Pekanbaru. Dari hasil wawancara diperoleh informasi bahwa materi yang dianggap sulit oleh siswa kelas XI selama ini adalah materi geometri, termasuk geometri bidang, ruang dan geometri transformasi. Pada penelitian ini, materi yang dipilih adalah materi geometri transformasi, dikarenakan materi tersebut akan dipelajari setelah materi geometri bidang yang sedang berlangsung telah selesai dipelajari. Dari hasil wawancara juga diketahui bahwa siswa kelas XI telah memiliki pengetahuan mengenai materi prasyarat yang diperlukan untuk mempelajari geometri transformasi. Untuk mempelajari materi geometri transformasi, siswa harus telah memahami materi fungsi dan geometri (Nu'man, 2015, p.349). Materi fungsi telah dipelajari di semester sebelumnya dan materi geometri bidang dipelajari sebelum materi geometri transformasi. Sarana dan prasarana sekolah juga telah memadai untuk mendukung pembelajaran menggunakan video berbasis Geogebra, seperti ketersediaan infokus, layar infokus, spidol, papan tulis, alat menggambar, dan tenaga listrik, sedangkan speaker peneliti bawa sendiri karena tidak tersedia di sekolah.

Sebelum diberikan perlakuan (pembelajaran menggunakan video berbasis Geogera untuk kelas eksperimen dan pembelajaran konvensional/ekspositori pada kelas kontrol), kelas kontrol dan kelas eksperimen diberikan tes awal terlebih dahulu. Tes yang digunakan pada kedua kelas tersebut adalah sama. Begitupun setelah perlakuan masing-masing kelas juga diberikan tes akhir yang sama. Data yang diperoleh dari tes awal dan tes akhir tersebut kemudian dianalisis. Sebelum melakukan analisis data secara inferensial, dilakukan analisis deskriptif terlebih dahulu. Hasil analisis deskriptif disajikan pada Tabel 1.

Tabel 1. Statistik Deskriptif Kemampuan Pemahaman Konsep Matematis

\begin{tabular}{|c|c|c|c|c|}
\hline & Statistik & $\begin{array}{c}\text { Kontrol } \\
N=35\end{array}$ & $\begin{array}{c}\text { Eksperimen } \\
N=38\end{array}$ & Skor Ideal \\
\hline \multirow[t]{2}{*}{ Tes awal } & Rata-rata $(\bar{x})$ & 13,37 & 13,69 & \multirow{6}{*}{50} \\
\hline & Simpangan Baku & 4,15 & 5,42 & \\
\hline \multirow[t]{2}{*}{ Tes akhir } & Rata-rata $(\bar{x})$ & 33,58 & 42,14 & \\
\hline & Simpangan Baku & 5,15 & 4,29 & \\
\hline \multirow[t]{2}{*}{ Gain } & Rata-rata $(\bar{x})$ & 0,56 & 0,79 & \\
\hline & Simpangan Baku & 0,13 & 0,10 & \\
\hline
\end{tabular}

Tabel 1 memperlihatkan bahwa rata-rata kemampuan awal pemahaman konsep matematis siswa di kedua kelompok tidak jauh berbeda, artinya siswa di kelompok eksperimen dan kelompok kontrol memiliki kemampuan pemahaman konsep yang relatif sama. Hal tersebut juga terkonfirmasi dari hasil uji- $t$, yang menunjukkan bahwa rata-rata skor tes awal kelas kontrol dan eksperimen adalah sama $(d f=$ $71 ; p$-value $=0,779$ )

Tabel 1 juga memperlihatkan rata-rata skor tes akhir dan nilai $n$-gain kelompok eksperimen lebih tinggi dibandingkan kelompok kontrol. Rata-rata skor tes akhir kelompok eksperimen 8,56 poin lebih tinggi dibandingkan kelompok kontrol dengan perbedaan $n$-gain sebesar 0,23 poin. Selain itu, skor tes akhir dan $n$-gain kelas eksperimen terlihat lebih bervariasi dibandingkan kelompok kontrol. Untuk menguji apakah perbedaan rata-rata skor $n$-gain ini signifikan, maka dilakukan uji terhadap rata-rata skor $n$-gain. Terlebih dahulu dilakukan uji normalitas dan homogenitas terhadap rata-rata skor $n$-gain. Hasil uji normalitas terhadap rata-rata skor n-gain dapat dilihat pada Tabel 2.

Tabel 2. Hasil Uji Normalitas Rata-rata Skor Gain Ternormalisasi

\begin{tabular}{lccc}
\hline \multicolumn{1}{c}{ Kelompok } & $t$ & $d f$ & $p$-value \\
\hline Eksperimen & 0,970 & 35 & 0,45 \\
Kontrol & 0,811 & 38 & 0,00 \\
\hline
\end{tabular}

Dari Tabel 2 dapat dilihat bahwa rata-rata skor $n$-gain kelompok eksperimen berdistribusi normal $(p$-value $=0,45)$, namun tidak pada kelompok kontrol $(p$-value $=0,00)$. Karena rata-rata skor $n$-gain salah satu kelompok tidak berdistribusi normal, maka dilakukan uji statistik nonparametrik U-Mann 
Whitney untuk menguji hiptesis penelitian. $\mathrm{H}_{0}$ ditolak jika nilai signifikansi lebih kecil dibandingkan taraf signifikan $\alpha=0,05$ dan $\mathrm{H}_{0}$ diterima untuk kondisi lainnya. Hasil uji non-parametrik U-Mann Whitney terhadap rata-rata $n$-gain dapat dilihat pada Tabel 3.

Tabel 3. Hasil Uji U Mann-Whitney Rata-rata N-Gain

\begin{tabular}{lc}
\hline & $N$-Gain \\
\hline Uji Mann-Whitney & 78.500 \\
Asymp.Sig.(2-tailed) & 0,00 \\
Kesimpulan & Tolak $\mathrm{H}_{0}$ \\
\hline
\end{tabular}

Dari uji U-Mann Whitney diperoleh $p$-value $=0,00$. Nilai ini lebih kecil dari nilai $\alpha$, maka tidak cukup untuk menerima $\mathrm{H}_{0}$. Hasil tersebut menunjukkan bahwa terdapat perbedaan signifikan peningkatan kemampuan pemahaman konsep kelompok eksperimen dan kelompok kontrol. Hal ini membuktikan bahwa terdapat perbedaan yang signifikan peningkatan kemampuan pemahaman konsep matematis siswa antara yang belajar menggunakan video berbasis Geogebra dengan siswa yang memperoleh pembelajaran konvensional. Dengan demikian, video pembelajaran berbasis Geogebra ini efektif untuk meningkatkan kemampuan pemahaman konsep matematis siswa, khususnya pada materi geometri transformasi, karena peningkatan skor kemampuan pemahaman konsepnya lebih tinggi dibandingkan pembelajaran konvensional (Lihat Tabel 1).

\section{Pembahasan}

Materi geometri sangat sesuai dipelajari dengan menggunakan video, sebagaimana yang dikemukakan oleh Gambari, James dan Olumorin (2014, p.83) bahwa pembelajaran dengan video dapat meningkatkan hasil belajar geometri siswa. Institute for Teaching and Learning Innovation (2017, p.1) menyatakan bahwa keuntungan penggunaan video bagi pendidikan diantaranya adalah meningkatkan motivasi siswa, menambah pengalaman belajar dan memfasilitasi kemampuan berpikir serta memecahkan masalah. Hasil penelitian Arbain dan Shukor (2015, p.213) menyimpulkan bahwa siswa memiliki persepsi positif terhadap Geogebra dalam hal minat, kepercayaan diri dan motivasi. Penggunaan video pembelajaran berbasis Geogebra ini juga sesuai dengan perkembangan teknologi masa kini. Tren masa kini dalam pembelajaran sains membutuhkan penggunaan teknik visualisasi dan Geogebra sangat sempurna bagi tren tersebut (Majerek, 2014, p.54). Media ini juga sangat cocok digunakan di negara berkembang seperti Indonesia, karena tidak memerlukan internet dalam penggunaannya dan sofware Geogebra dapat diunduh dan digunakan secara bebas serta tersedia dalam pilihan Bahasa Indonesia (Nopiyani, Turmudi, \& Prabawanto, 2016, p.3).

Video pembelajaran merupakan media pembelajaran yang komunikatif dan dapat ditayangkan ulang sesuai kebutuhan, menampilkan sesuatu dengan detail dan kompleks, dapat dipercepat, diperlambat, bahkan diperbesar dan membandingkan antara dua atau lebih adegan secara bersamaan (Majid, 2012, p.180). Keunggulan ini membuat pembelajaran matematika yang bersifat abstrak menjadi lebih konkret, tidak monoton dan tidak membosankan. Siswa dapat menjadi lebih aktif terlibat dalam membangun pengetahuan mereka dengan bantuan video digital serta mengeksplorasi dunia matematika yang menakjubkan (Niess \& Walker, 2010, p.101). Selain itu, video pembelajaran menggabungkan banyak data (gambar, gerak, suara dan teks) dalam mode yang komplit sehingga pembelajaran dapat lebih mudah dilakukan, karena tidak harus membagi siswa berdasarkan gaya belajarnya (Greenberg \& Zanetis, 2012, p.19). Perkins dan Salomon (Woolfitt, 2015, p.23) menyatakan bahwa pembelajaran dengan video melibatkan siswa secara aktif sehingga memberikan keuntungan bagi siswa untuk mentransfer pengetahuannya sehingga diperoleh pemahaman yang lebih dalam dan kompleks. Hal ini didukung pula oleh hasil penelitian Albaniah (2014, p.5) bahwa terdapat hubungan yang positif antara penggunaan media video dengan hasil belajar matematika siswa. Video pembelajaran mampu menggabungkan dan mengintegrasikan berbagai metode dan teknik pembelajaran yang efektif membantu siswa dalam proses pembelajaran di kelas dan dapat meningkatkan hasil dan motivasi belajar siswa (Ziden \& Rahman, 2013, p. 220).

Selain itu, penggunaan software Geogebra dalam produksi video pembelajaran matematika menghemat waktu untuk menggambar di papan tulis dan melakukan perhitungan, sehingga lebih banyak waktu yang dapat digunakan untuk belajar mengeksplorasi materi. Ljajko dan Ibro (2013, p.1) mengemukakan bahwa Geogebra dapat membantu memaksimalkan efesiensi proses pembelajaran, menjadikan siswa berpartisipasi aktif dalam proses membangun pengetahuan dan merubah eksplorasi 
statis menjadi dinamis dalam pembelajaran geometri. Geogebra merupakan software yang mampu menghasilkan visualisasi yang lebih dinamis bagi materi geometri dibanding software lainnya seperti Cabri 3D (Fitriyani \& Sugiman, 2014, p.270). Geogebra dapat membantu siswa dalam merepresentasikan pemahaman konsep dengan berbagai cara, yang mempengaruhi kemampuan belajar matematis siswa (Baghat \& Chang, 2015, p.82). Geogebra dapat membantu siswa memahami makna dari suatu konsep (Majerek, 2014, p. 54). Software matematika seperti Geogebra memberikan kontribusi positif terhadap aktivitas pembelajaran, visualisasi, menjadikan konsep yang abstrak menjadi konkret, sehingga menghasilkan pembelajaran yang lebih efektif (Tatar, 2013, p.1). Software Geogebra meningkatkan visualisasi dan pemahaman konsep, baik siswa maupun guru (Thambi \& Leong, 2013, p.105). Suweken (2013, p.284) menyatakan penggunaan media virtual berbasis Geogebra dapat membantu siswa memahami konsep matematika dan meningkatkan keterlibatan siswa dalam pembelajaran. Hasil penelitian Praveen dan Leong (2016, p.7) menyebutkan bahwa Geogebra dapat digunakan dalam pembelajaran matematika dan secara signifikan mampu meningkatkan pemahaman konsep matematis siswa. Hutkemri (2014, p.879), Zulnaidi dan Zamri (2017, p.2160) menyimpulkan hasil penelitiannya bahwa penggunaan software Geogebra efektif meningkatkan pemahaman konsep dan kemampuan prosedural siswa. Kombinasi keunggulan video dan keefektifan software Geogebra menjadikan pembelajaran matematika yang dianggap abstrak menjadi konkret, menyenangkan, tidak membosankan, menimbulkan motivasi belajar matematika, menjadikan siswa aktif dalam mengeksplorasi matematika lebih mendalam, sehingga menjadikan pembelajaran lebih bermakna bagi siswa. Siswa secara langsung dapat melihat perubahan posisi, bentuk dan ukuran setiap objek geometri yang ditransformasikan, serta mendengarkan penjelasan dari setiap perubahan yang terjadi. Tayangan video pembelajaran berbasis Geogebra tersebut menjadikan matematika, khususnya materi geometri transformasi yang selama ini dianggap abstrak dan sulit menjadi konkret dan bermakna, sehingga mudah untuk dipahami. Sebagaimana dikemukakan oleh Mayer $(2009$, p.278) bahwa pengintegrasian kata-kata dan gambar-gambar yang relevan merupakan kunci pembelajaran yang penuh makna. Hal inilah yang menyebabkan pembelajaran menggunakan video pembelajaran berbasis Geogebra mampu meningkatkan pemahaman siswa terhadap suatu konsep matematika.

Hasil penelitian menunjukkan bahwa setiap siswa yang memperoleh pembelajaran dengan video berbasis Geogebra mampu meningkatkan kemampuan pemahaman konsep matematisnya. Sebanyak 88,57\% siswa di kelompok eksperimen memperoleh kenaikan di atas 0,7 atau high gain, sisanya berada pada level medium gain. Peningkatan ini mengindikasikan bahwa pembelajaran video berbasis Geogebra berpengaruh positif terhadap kemampuan pemahaman konsep matematika di setiap level pengetahuan (Majerek, 2014, p.54) dan dapat digunakan di setiap jenjang pendidikan, dari dasar hingga tinggi (Tatar, 2013, p.2), bahkan bagi calon guru. Star dan Strickland (2008, p.107) mengungkapkan bahwa penggunaan video pembelajaran meningkatkan kemampuan observasi calon guru, khususnya kemampuan guru untuk memperhatikan karakteristik lingkungan kelas, konten pembelajaran matematika, dan komunikasi antara guru dan siswa selama pembelajaran.

Meskipun memiliki banyak keuntungan dalam penggunaannya, namun video tidak bisa dijadikan media pembelajaran untuk setiap pertemuan atau tatap muka. Hal ini dikarenakan akan menghadirkan sesuatu yang monoton dan membosankan. Mayer (2009, p.273) menyatakan bahwa penggunaan multimedia learning, seperti video akan memberikan pengaruh yang lebih baik jika narasi dan animasi disajikan dalam segmen pendek dan berselang-seling. Fabris (2015) mengungkapkan bahwa siswa tidak menyukai video dengan pengeras suara yang monoton, menimbulkan rasa gugup atau tidak membuat kontak mata ke kamera. Durasi video yang ideal adalah sekitar 5 sampai 20 menit. Untuk mencegah kebosanan, maka guru sebagai fasilitator dapat menghentikan video dan memberikan tantangan kepada siswa untuk memprediksi lanjutan dari suatu tayangan, mendemonstasikan, mengelaborasi atau berdiskusi mengenai hal tersebut. Guru juga dapat merewind sebagian tayangan untuk memberikan ulasan tambahan untuk memastikan siswa memahami konsep utama yang ingin disampaikan. Ditambah lagi, merencanakan dan membuat video memerlukan waktu dan persiapan yang lebih banyak dibandingkan pembelajaran biasanya. Guru harus mempertimbangkan topik apa yang menjadi konten utama (kunci), bagaimana cara paling mudah dan sederhana untuk menampilkan konten tersebut tanpa kehilangan bagian terpentingnya (Korpela, 2015, p.78). 


\section{SIMPULAN}

Pembelajaran matematika hendaknya tidak terfokus sebatas teori saja, tetapi juga menggunakan pendekatan, strategi ataupun media pembelajaran yang bervariasi yang dapat menarik minat belajar siswa dan membantu siswa memahami konsep secara mendalam serta mampu mengembangkan kecakapan matematis. Hasil peneltian ini menunjukkan bahwa peningkatan kemampuan pemahaman konsep matematis siswa yang belajar menggunakan video berbasis Geogebra lebih baik dibandingkan siswa yang belajar dengan pembelajaran konvensional. Dengan demikian, pembelajaran matematika dengan video berbasis Geogebra memberikan pengaruh positif terhadap peningkatan kemampuan pemahaman konsep matematis siswa. Video pembelajaran berbasis Geogebra ini dapat menjadi variasi media pembelajaran matematika yang efektif, efesien dan terbukti ampuh untuk meningkatkan kemampuan pemahaman konsep matematis siswa.

Berdasarkan hasil penelitian, peneliti menyarankan beberapa hal. Pertama, video pembelajaran berbasis Geogebra hendaknya dijadikan sebagai variasi media yang mendukung pembelajaran matematika. Kedua, dalam proses pembelajaran menggunakan video berbasis Geogebra, selain memperhitungkan ketersediaan alat pendukung, guru juga perlu memperhatikan kondisi alat bantu tersebut, seperti penempatan layar infokus, kualitas gambar serta suara yang dihasilkan. Ketiga, ketika menggunakan video pembelajaran berbasis Geogebra ini, guru harus mengatur waktu penggunaan video, menghentikan, melanjutkan atau merewind sebagian tayangan untuk mencegah kebosanan dan memastikan siswa memahami konsep yang sedang diajarkan. Keempat, perlu dilakukan perbaikan dari sesi desain, materi dan suara dalam pembuatan video pembelajaran berbasis Geogebra sehingga dihasilkan video pembelajaran yang berdaya jual secara ekonomis.

\section{DAFTAR PUSTAKA}

Afgani, D.J. (2011). Analisis kurikulum matematika. Jakarta: Universitas Terbuka.

Albaniah, T. (2014). Hubungan penggunaan media video pembelajaran dengan hasil belajar siswa pada mata pelajaran matematika kelas IV SD 76/1 Sungai Buluh. Retrieved from http://ecampus.fkip.unja.ac.id/eskripsi/data/pdf/jurnal_mhs/artikel/A1D109136.pdf

Alviah, E. E., \& Rudhito, M. A. (2012). Efektivitas pembelajaran dengan program Geogebra dibanding pembelajaran konvensional pada topik grafik fungsi kuadrat kelas X SMA Pangudi Luhur Yogyakarta. Prosiding Seminar Nasional Matematika dan Pendidikan Matematika, FMIPA Universitas Negeri Yogyakarta, 279-288. Retrieved from https://eprints.uny.ac.id/7562/

Ambussaidi, I., \& Yang, Y. (2019). The impact of mathematics teacher quality on student achievement in Oman and Taiwan. International Journal of Education and Learning, 1(2), 50-62. doi:https://doi.org/10.31763/ijele.v1i2.39

Amir, Z. (2015). Mengungkap seni bermatematika dalam pembelajaran. Suska Journal of Mathematics Education, 1(1), 60-76. http://dx.doi.org/10.24014/sjme.v1i1.1364

Annajmi. (2016). Peningkatan kemampuan pemahaman konsep matematika siswa SMP melalui metode penemuan terbimbing berbantuan software Geogebra. Journal of Mathematics Education and Science, 2(1), 1-10. https://doi.org/10.30743/mes.v2i1.110

Arbain, N., \& Shukor, N. A. (2015). The effect of geogebra on students achievement. Procedia Social and Behavioral Sciences, 172, 208-214. doi:http://doi.org/10.1016/j.sbspro.2015.01.356

Azis, A., \& Sugiman, S. (2015). Analisis kesulitan kognitif dan masalah afektif siswa SMA dalam belajar matematika menghadapi ujian nasional. Jurnal Riset Pendidikan Matematika, 2(2), 162174. doi:https://doi.org/10.21831/jrpm.v2i2.7331

Baghat, K. K., \& Chang, C. Y. (2015). Incorporating geogebra into geometri learning-a lesson from India. Eurasia Journal of Mathematics, Science \& Technology Education, 11(1), 77-86. doi:https://doi.org/10.12973/eurasia.2015.1307a

Baharuddin, I. (2014). Efektivitas penggunaan media video tutorial sebagai pendukung pembelajaran matematika terhadap minat dan hasil belajar peserta didik SMA Negeri 1 Bajo Kabupaten Luwu Sulawesi Selatan. Jurnal Nalar Pendidikan, 2(2), 247-255. doi:https://doi.org/10.26858/jnp.v2i2.1974 
Bu, L., \& Haciomeroglu, E. S. (2010). Geogebra in mathematics teacher education: In case of quadratic relations. MSOR Connections, 10(1), 1-9. Retrieved from https://www.heacademy.ac.uk/system/files/msor.10.1c.pdf

Busyaeri, A., Udin, T., \& Zaenudin, A. (2016). Pengaruh penggunaan video pembelajaran terhadap peningkatan hasil belajar mapel IPA di MIN Kroya Cirebon. Al Ibtida: Jurnal Pendidikan Guru MI, 3(1), 116-137. doi:http://dx.doi.org/10.24235/al.ibtida.snj.v3i1.584

Fabris, C. (2015). Videos find their place in and out of the classroom. Chronicle of Higher Education. Retrieved from https://www.chronicle.com/blogs/wiredcampus/videos-find-their-place-in-andout-of-the-classroom/56113

Fitriyani, W., \& Sugiman, S. (2014). Pengembangan perangkat pembelajaran teorema Pythagoras dengan pendekatan IDEAL berbantuan Geogebra. Jurnal Riset Pendidikan Matematika, 1(2), 268-283. doi:https://doi.org/10.21831/jrpm.v1i2.2681

Gambari, I. A., James, M., \& Olumorin, C. O. (2014). Effectiveness of video-based cooperative learning strategy on high, medium dan low academic achievers. The African Symposium: An online journal of the African Educational Research Network, 13(2), 77-85.

Greenberg, D., \& Zanetis, J. (2012). The impact of broadcast and streaming video in education. Report Commissioned by Cisco Systems Inc. to Wainhouse Research, LLC. Retrieved from https://www.cisco.com/c/dam/en_us/solutions/industries/docs/education/ciscovideowp.pdf

Hake, R. R. (1998). Interactive-engagement versus traditional methods : a six-thousand-students survey of machanics test data for introductory physics courses. American Journal of Physics, 66(1), 6474. doi:http://dx.doi.org/10.1119/1.18809

Hamzah, A., \& Muhlisrarini, M. (2014). Perencanan dan strategi pembelajaran matematika. Depok: Raja Grafindo Persada.

Haryoko, S. (2009). Efektivitas pemanfaatan media audio-visual sebagai alternatif optimalisasi model pembelajaran. Jurnal Edukasi Elektro, 5(1), 1 -10. Retrieved from http://id.portalgaruda.org/index.php?ref=browse \&mod=viewarticle\&article=52435

Hosnan, M. (2014). Pendekatan saintifik dan kontekstual dalam pembelajaran abad 21. Bogor: Ghalia Indonesia.

Hutkemri, E. Z. (2014). Impact of using Geogebra on students' conceptual and procedural knowledge of limit function. Mediterranean Journal of Social Sciences, 5(23), 873-881. doi: https://dx.doi.org/10.5901/mjss.2014.v5n23p873

Institute for Teaching and Learning Innovation. (2017). Pedagogical benefit. Brisbane St Lucia, QLD: The University of Queensland. Retrieved from http://www.uq.edu.au/teach/video-teachlearn/ped-benefits.html

Johari, A., Hasan, S., \& Rakhman, M. (2014). Penerapan media video dan animasi pada materi memvakum dan mengisi refrigran terhadap hasil belajar siswa. Journal of Mechanical Engineering Education, 1(1), 8-15. doi:http://dx.doi.org/10.17509/jmee.v1i1.3731

Kementerian Pendidikan dan Kebudayaan Republik Indonesia. (2016). Peraturan menteri pendidikan dan kebudayaan nomor 21 tahun 2016 tentang standar isi pendidikan dasar dan menengah.

Kesumawati, N. (2008). Pemahaman konsep matematik dalam pembelajaran matematika. Prosiding Seminar Nasional Matematika dan Pendidikan Matematika FMIPA Universitas Negeri Yogyakarta, 229-235. Retrieved from https://eprints.uny.ac.id/6928/

Khuzaini, N., \& Santosa, R. H. (2016). Pengembangan multimedia pembelajaran trigonometri menggunakan Adobe Flash CS3 untuk Siswa SMA. Jurnal Riset Pendidikan Matematika, 3(1), 88-99. doi:https://doi.org/10.21831/jrpm.v3i1.9681

Korpela, H. K. (2015). Using short video lectures to enhance mathematics learning-experiences on differential and integral calculus course for engineering students. Informatics Education, 14(1), 67-81. doi:https://doi.org/10.15388/infedu.2015.05

Ljajko, E., \& Ibro, V. (2013). Development of ideas in Geogebra-aided mthematics instruction. Mevlana $\begin{array}{lllllll}\text { International Journal of } & \text { Education } & \text { (MUE), } & 3(3), & 1 & -7 .\end{array}$ doi:https://doi.org/10.13054/mije.si.2013.01 
Ma'ruf, A. (2016). Pengembangan media video pembelajaran berbasis Geogebra untuk meningkatkan kemampuan pemahaman konsep matematika siswa sekolah menengah kejuruan (Skripsi tidak diterbitkan). UIN Sultan Syarif Kasim, Riau.

Mahmudi, A. (2010). Membelajarkan geometri dengan program Geogebra. Prosiding Seminar Nasional Matematika dan Pendidikan Matematika FMIPA Universitas Negeri Yogyakarta, 469-477. Retrieved from https://eprints.uny.ac.id/10483/

Majerek, D. (2014). Application of Geogebra for teaching mathematics. Advances in Sciences and Technology Research Journal, 8(24), 51-54. doi:https://doi.org/10.12913/22998624/567

Majid, A. (2012). Perencanaan pembelajaran. Bandung: Remaja Rosda Karya.

Marzuqo, K. (2014). Geometri transformasi. Pekanbaru: Benteng Media.

Mayer, R. E. (2009). Multimedia learning: Prinsip-prinsip dan aplikasinya (T. W. Utomo, Trans.). Yogyakarta: Pustaka Pelajar. (Original work published 2009).

Meltzer, D. E. (2002). The relationship between mathematics preparation and conceptual learning gains in physics: A possible "hidden variable" in diagnostic pretest scores. American Journal of Physics, 7(12), 1259-1268. doi:https://doi.org/10.1119/1.1514215

Mullis, I. V. S., Martin, M. O., Foy, P., \& Hooper, M. (2016). TIMSS 2015 international result in mathematics. B oston, MA: Boston College, TIMSS \& PIRLS International Study Center Retrieved from http://timssandpirls.bc.edu/timss2015/international-results/

Mulyatiningsih, E. (2013). Metode penelitian terapan bidang pendidikan. Bandung: Alfabeta.

Munir, M. (2013). Multimedia: konsep dan aplikasi dalam pendidikan. Bandung: Alfabeta.

Murizal, A., Yarman, Y., \& Yerizon, Y. (2012). Pemahaman konsep matematis dan model pembelajaran quantum teaching. Jurnal Edukasi dan Penelitian Matematika, 1(1), 19-23.

Niess, M. L., \& Walker, J. M. (2010). Guest editorial: digital videos as tools for learning mathematics. Contemporary Issues in Technology and Teacher Education, 10(1), 100-105. Retrieved from https://www.citejournal.org/volume-10/issue-1-10/mathematics/guest-editorial-digital-videosas-tools-for-learning-mathematics

Nopiyani, D., Turmudi., \& Prabawanto, S. (2016). Penerapan matematika realistik berbantuan Geogebra untuk meningkatkan kemampuan komunikasi matematis siswa SMP. MUSHORAFA: Jurnal Pendidikan Matematika, 8(1), 1-8. doi:https://doi.org/10.31980/mosharafa.v5i2.259

Nu'man, M. (2015). Pengembangan bahan ajar geometri transformasi berdasarkan problem based learning untuk memfasilitasi kemampuan komunikasi matematis mahasiswa pendidikan matematika UIN Sunan Kalijaga. Prosiding Seminar Nasional Matematika dan Pendidikan Matematika UMS. Universitas Muhammadiyah Surakarta, Surakarta. Retrieved from http://hdl.handle.net/11617/5968

Nur, I. M. (2016). Pemanfaatan program Geogebra dalam pembelajaran matematika. Delta-Pi: Jurnal Matematika dan Pendidikan Matematika, 5(1), 10-19. Retrieved from https://ejournal.unkhair.ac.id/index.php/deltapi/article/view/236/0

Nurdin, E., \& Nufus, H. (2017). Desain pengembangan kurikulum matematika. Pekanbaru: Cahaya Firdaus.

OECD. (2016). PISA 2015 result in focus. Retrieved from http://www.oecd.org/pisa/pisa-2015-resultsin-focus.pdf

Prastowo, A. (2011). Panduan kreatif membuat bahan ajar inovatif. Yogjakarta: DIVA Press.

Praveen, S., \& Leong, K. E. (2016). Effectiveness of using Geogebra on students understanding in learning circles. The Malaysian Online Journal of Educational Technology, 1(4), 1-9. Retrieved from http://www.mojet.net/article/effectiveness-of-using-geogebra-on-students-understandingin-learning-circles

Purwanti, B. (2015). Pengembangan video pembelajaran matematika dengan model assure. Jurnal Kebijakan dan Pengembangan Pendidikan, 3(1), 42-47. Retrieved from http://ejournal.umm.ac.id/index.php/jmkpp/article/view/2194 
Riduwan, R. (2015). Belajar mudah penelitian untuk guru-karyawan dan peneliti pemula. Bandung: Alfabeta.

Star, J. R., \& Strickland, S. K. (2008). Learning to observe: Using video to improve preservice mathematics teachers' ability to notice. Journal Mathematics Teacher Education, 11(2), 107-125. doi:http://dx.doi.org/10.1007/s10857-007-9063-7

Sugiyono. (2014). Metode penelitian kuantitatif, kualitatif dan $R \& D$. Bandung: Alfabeta.

Suweken, G. (2013). Pengintegrasian Media pembelajaran virtual berbasis Geogebra untuk meningkatkan keterlibatan dan pemahaman konsep matematika siswa kelas VIII SMP Singaraja. Jurnal Pendidikan Indonesia, 2(2), 276-285. doi:http://dx.doi.org/10.23887/jpiundiksha.v2i2.2172

Tatar, E. (2013). The effect of dynamic software on prospective mathematics teachers' perception regarding information and communication technology. Australian Journal of Teacher Education, 38(12),1-8. doi:http://doi.org/10.14221/ajte.2013v38n12.6

Thambi, N., \& Leong, K. E. (2013). Effect of students' achievement in fractions using Geogebra. Sainsab, 16, 97-106. Retrieved from https://umexpert.um.edu.my/file/publication/00010213_95273.pdf

Trianto, T. (2011). Mendesain model pembelajaran inovatif-progresif. Jakarta: Kencana Prenada Media Grup.

Vieira, I., Lopes, A. P., \& Soares, F. (2014). The potential benefit of using video in higher education. Proceeding of Edulearn 14 Conference, Barcelona, 750-756. Retrieved from https://core.ac.uk/download/pdf/47139700.pdf

Wahyudin, W. (2008). Pembelajaran dan model-model pembelajaran. Bandung: Universitas Pendidikan Indonesia.

Woolfitt, Z. (2015). The effective use of video in higher education. Retrieved from https://www.inholland.nl/media/10230/the-effective-use-of-video-in-higher-education-woolfittoctober-2015.pdf

Ziden, A. A., \& Rahman, M. F. A. (2013). The effectiveness of web-based multimedia applications simulation in teaching and learning. International Journal of Instruction, 6(2), 211-222. Retrieved from http://www.e-iji.net/dosyalar/iji_2013_2_14.pdf

Zulnaidi, H., \& Zamri, S. N. A. S. (2017). The effectiveness of Geogebra software: The intermediary role of procedural knowledge on students' conceptual knowledge and their achievement in mathematics. Eurasia Journal of Mathematics Science and Technology Education, 13(6), 21552180. doi:https://doi.org/10.12973/eurasia.2017.01219a 